\title{
Magnesium induced vascular relaxation and role of Calcium-dependent $\mathrm{K}^{+}$Channels
}

\author{
Upadhyay-Dhungel $\mathrm{K}^{*}, 1$, Kim CJ ${ }^{*}$, Dhungel $\mathrm{A}^{2}$ \\ Department of Neurosurgery, Chonbuk National University Medical School, South Korea \\ *Department of Neurosurgery, Chonbuk National University Medical School, South Korea \\ ${ }^{1}$ Associate Professor, Department of Physiology, Janaki Medical College, Janakpurdham, Nepal \\ ${ }^{2}$ Department of Internal Medicine, King Edward Medical University, Lahore, Pakistan
}

\section{ABSTRACT}

Background and objectives: Magnesium is established as a neuro-protective agent and now also known as a vasodilator. It has been known for treating vasospasm following subarachnoid hemorrhage. However, its action mechanism in cerebral vascular relaxation is not clear. Potassium channels play a pivotal role in the relaxation of smooth muscle cells. To investigate their role in magnesium-induced relaxation of basilar smooth muscle cells, we examined the effect of magnesium on potassium channels using the patch clamp technique on cells from rabbit basilar artery.

Material and Methods: Fresh smooth muscle cells were isolated from the basilar artery by enzyme treatment. Whole cell current recording was done using patch-clamp technique. Appropriate bath solution was used to have potassium current. The effect of Magnesium was observed and to identify the potassium $\left(\mathrm{K}^{+}\right)$channel involved in the magnesium-induced currents, different potassium channel blockers were used.

Results: Magnesium increased the step pulse-induced outward $\mathrm{K}^{+}$currents by more than fortyfive percent over control level $(p<0.01)$. The outward $\mathrm{K}^{+}$current was decreased significantly by application of tetraethylammonium, a non-specific $\mathrm{K}^{+}$channel blocker, and by iberiotoxin, a largeconductance $\mathrm{Ca}^{2+}$-activated $\mathrm{K}^{+}\left(\mathrm{BK}_{\mathrm{Ca}}\right)$ channel blocker, but was not inhibited by glibenclamide an ATP-sensitive $\mathrm{K}^{+}\left(\mathrm{K}_{\mathrm{ATP}}\right)$ channel blocker. Magnesium failed to increase the outward $\mathrm{K}^{+}$currents in the presence of IBX.

Conclusion: These results demonstrate that calcium dependent pottassium $\left(\mathrm{BK}_{\mathrm{Ca}}\right)$ channels has role in magnesium induced vascular relaxation in rabbit basilar smooth muscle cells and needs to be worked out for human.

Keywords: electrophysiology; Magnesium; Patch clamp; vasoconstriction 


\section{INTRODUCTION}

Cerebral vasospasm following subarachnoid hemorrhage $(\mathrm{SAH})$ is one of the major causes of cerebral ischemia and is the leading cause morbidity and mortality [1]. Currently, the most common therapeutic approaches to vasospasm are the use of calcium antagonists and triple $\mathrm{H}$ therapy along with chemical angioplasty, non detachable silicone ballons angioplasty etc. However, the reported outcome remains rather modest and the best form of treatment for SAH vasospasm is still not clear [2]. Because of this, adjunctive therapies are being developed based on etiology of vasospasm at cellular level. Magnesium is one of the adjuncts being used. Several experimental and recent clinical studies have demonstrated the beneficial effects, safety and feasibility of use of magnesium in SAH [2-7]. Magnesium is a well-known vasodilator and is thought to act on potassium channels to exert its vasodilatory effect [8]. The activation of potassium channels induces potassium ion efflux and then causes membrane hyperpolarization, which initiates the relaxation of vascular smooth muscle cells and thus prevents the vasospasm [9]. Here, we hypothesized that magnesium induced the relaxation of smooth muscle cells in the cerebro-vascular artery through potassium channel activation in rabbit. This study was therefore conducted to investigate the effect of magnesium on potassium channels in rabbit basilar smooth muscle cells and to clarify the role of potassium channels in magnesiummediated action.

\section{MATERIAL AND METHODS}

New Zealand (NZ) white adult rabbits (all male, weight $2.5-3 \mathrm{~kg}$ ) were used in the experiment. Smooth muscle cells were isolated from the basilar artery by enzyme treatment. Isolated cells stained positive for $\alpha$-actin and
The cells were used within 24 hours of enzymatic treatment.

Whole-cell current recording:

Cells were voltage-clamped using the whole-cell patch clamp technique [8-10]. Membrane current data were collected and amplified using the patch clamp Axon-patch 200B and Clampex 7 programs (Axon Instruments). Data analysis was performed using Clampfit 9. All experiments were carried out at room temperature $\left(20 \sim 25{ }^{\circ} \mathrm{C}\right)$. To identify which potassium channels are involved in the magnesium-induced currents, we used the potassium channel blockers tetraethylammonium (TEA), glibenclamide and iberiotoxin (IBX).

\section{Solutions and drugs:}

To record the $\mathrm{Ca}^{2+}$-activated $\mathrm{K}^{+}$current, the bath solution for whole-cell recording contained (in $\mathrm{mM}$ ): $\mathrm{NaCl}$ 136, $\mathrm{KCl} 5.4, \mathrm{Mg} \mathrm{Cl}_{2}$ 1.2, $\mathrm{CaCl}_{2}$ 1.8, HEPES 10, Glucose 5.2 and $\mathrm{pH}$ adjusted to 7.4 with $\mathrm{NaOH}$. The pipette solution contained (in $\mathrm{mM}$ ): $140 \mathrm{KCl}, \mathrm{CaCl}_{2} \quad 0.65$, ethylenebis (oxonitrilo) tetraacetic acid (EGTA) 3, HEPES 10 , Glucose 10 and $\mathrm{pH}$ adjusted to 7.4 with $\mathrm{KOH}$. The free calcium concentration in the pipette solution was estimated to be $10 \mathrm{nM}$. To identify which potassium channels are involved in the magnesium-induced currents, we used the potassium channel blockers tetraethylammonium (TEA), glibenclamide and iberiotoxin (IBX).

Data analysis:

Data are expressed as relative values to control level ( \pm S.E.M.). Differences between groups were assessed by paired t-test or one sample t-test to compare the relative values. 


\section{RESULTS}

To examine the effect of magnesium on $\mathrm{K}^{+}$ current in rabbit basilar artery smooth muscle, the membrane potentials were held at $-60 \mathrm{mV}$, depolarizing pulses were then applied in $20-\mathrm{mV}$ steps every 3 seconds for $600 \mathrm{~ms}$, and whole cell voltage clamp recordings were obtained [8]. Under control conditions, depolarizing pulses elicited outward $\mathrm{K}^{+}$currents; however, no marked inward current was observed in the same voltage ranges.

A typical trace showing increased outward $\mathrm{K}^{+}$ current following bath application of $5 \mathrm{mM}$ magnesium is shown in Figure 1. The outward $\mathrm{K}^{+}$current was recovered to the control level after washout. Figure 2 shows the relative outward $\mathrm{K}^{+}$currents. The outward $\mathrm{K}^{+}$current was increased by $46 \%(1.46 \pm 0.14, n=23)$ by application of $5 \mathrm{mM}$ magnesium $(p<0.01)$.
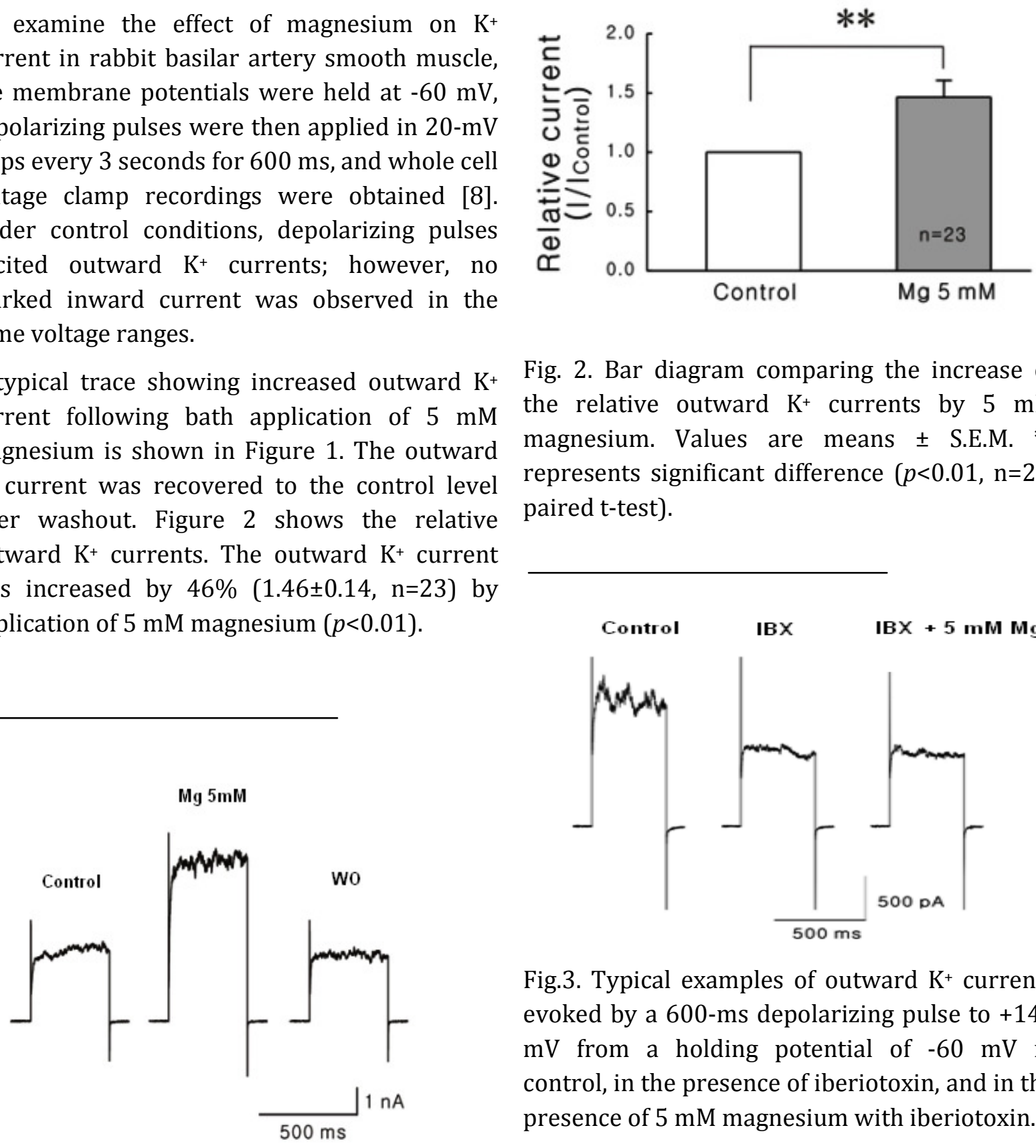

Fig. 2. Bar diagram comparing the increase of the relative outward $\mathrm{K}^{+}$currents by $5 \mathrm{mM}$ magnesium. Values are means \pm S.E.M. ** represents significant difference $(p<0.01, \mathrm{n}=23$, paired t-test).

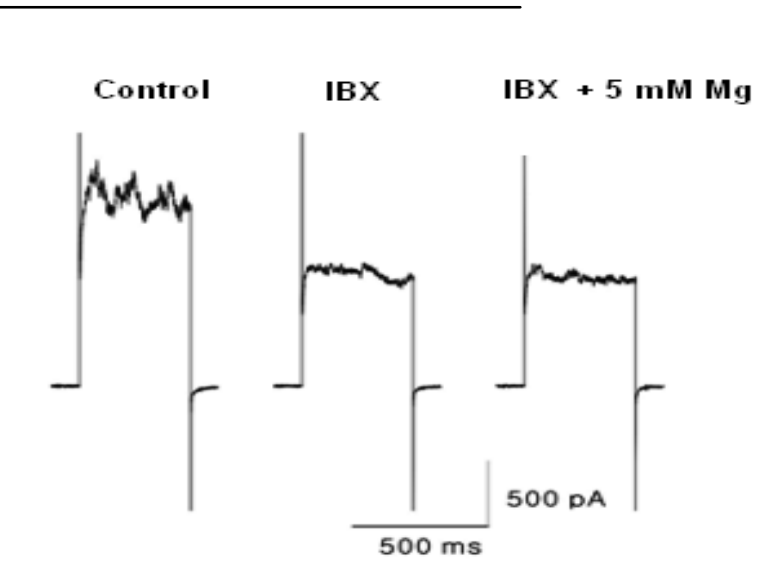

Fig.3. Typical examples of outward $\mathrm{K}^{+}$currents evoked by a 600 -ms depolarizing pulse to +140 $\mathrm{mV}$ from a holding potential of $-60 \mathrm{mV}$ in control, in the presence of iberiotoxin, and in the presence of $5 \mathrm{mM}$ magnesium with iberiotoxin.

Fig.1. Typical examples of outward $\mathrm{K}^{+}$currents evoked by a 600 -ms depolarizing pulse to +140 $\mathrm{mV}$ from a holding potential of $-60 \mathrm{mV}$ in control, in the presence of $5 \mathrm{mM}$ magnesium, and after washout.

The outward $\mathrm{K}^{+}$current was decreased significantly by TEA application $(p<0.01, n=3)$, and were not affected by glibenclamide ( $3 \mathrm{mM}$ ), an ATP-sensitive $\mathrm{K}^{+}$channel $\left(\mathrm{K}_{\mathrm{ATP}}\right)$ blocker. Calcium-dependent large conductance $\mathrm{K}$ channel blocker, iberiotoxin (IBX) alone significantly $(p<0.05, \mathrm{n}=3)$ decreased the 
outward $\mathrm{K}^{+}$current and magnesium $(5 \mathrm{mM})$ failed to increase the outward $\mathrm{K}^{+}$current in the presence of IBX, suggesting that $\mathrm{BK}_{\mathrm{Ca}}$ channels were involved in the magnesium-induced increase of outward $\mathrm{K}^{+}$current on basilar artery smooth muscle cells (Figure 3).

\section{DISCUSSION}

In this study, we examined the effect of magnesium on outward $\mathrm{K}^{+}$current induced by depolarizing pulse using the patch clamp technique and found that magnesium activated the $\mathrm{BK}_{\mathrm{Ca}}$ channel in rabbit basilar artery smooth muscle cells. This result could afford a logical mechanism for magnesium-induced vascular relaxation and provide background for the clinical use of magnesium, especially in treating vasospasm following SAH.

The activation of $\mathrm{BK}_{\mathrm{Ca}}$ channel by $\mathrm{Mg}^{2+}$ in intact cells could be explained in a number of ways. Magnesium could activate $\mathrm{BK}_{\mathrm{Ca}}$ channel by directly affecting the channel or a closely associated site [9-11] or indirectly by causing release of calcium from intracellular stores [12]. The current literature shows that the $\mathrm{Mg}^{2+}$ binding site is located in the intracellular RCK (regulator of conductance for $\mathrm{K}^{+}$) domain of the channel protein $[13,14]$. Binding of $\mathrm{Mg}^{2+}$ in the intracellular RCK domain opens the activation gate in $\mathrm{BK}_{\mathrm{Ca}}$ through an allosteric mechanism 1. $[13,14]$. Zhang et al. demonstrated a rapid rise in free $\left[\mathrm{Mg}^{2+}\right]_{i}$ by an increase in $\left[\mathrm{Mg}^{2+}\right]_{0}$ in cultured aorta vascular smooth muscle cells and mentioned that the rise in $\left[\mathrm{Mg}^{2+}\right]_{i}$ could be due to direct influx by a change in magnesium gradi ent, by carrier-mediated transport, partially by 3 . active transport and by magnesium buffering [15].
The rise in $\left[\mathrm{Mg}^{2+}\right]_{\mathrm{i}}$ can then internally act upon the $\mathrm{BK}_{\mathrm{Ca}}$ channel to activate the channel. Because of the large unitary conductance of $\mathrm{BK}_{\mathrm{Ca}}$ channels, the opening of this channel leads to quick hyperpolarization of the smooth muscle, thereby relaxing the cerebrovascular smooth muscle cells.

\section{CONCLUSION}

In summary, this study indicates that magnesium acts by increasing the conductance of $\mathrm{BK}_{\mathrm{Ca}}$ channels to exert its vasodilatory effect in basilar artery smooth muscle cells. This will provide some background for the clinical uses of magnesium as adjunct therapy for treating patient with subarachnoid hemorrhage.

\section{ACKNOWLEDGEMENT}

We would like to acknowledge that this research is a part of research work funded by BK-21 to the first author, research scholar of Cerebrovascular Lab, Neurosurgery, school of medicine, Chonbhuk University, South Korea. Authors would like to express our sincere thanks to Mr. Kim T from Medical school, Chonbuk National University, Korea for his help and support.

\section{REFERENCES}

Keyrouz SG, Diringer MN. Clinical review: Prevention and therapy of vasospasm in subarachnoid hemorrhage. Critical Care 2007; 11:220. (doi:10.1186/cc5958).

2. Dorsch NW. Therapeutic approaches to vasospasm in subarachnoid hemorrhage. Curr Opin Crit Care 2002; 8:128-33.

Alborch E, Salom JB, Perales AJ et al. Comparison of the anticonstrictor action of dihydropyridines (nimodipine and nicardipine) and $\mathrm{Mg}^{2+}$ in isolated human cerebral arteries. Eur J Pharmacol 1992; 229:83-9.

4. Stippler M, Crago E, Levy EI et al. Magnesium infusion for vasospasm prophylaxis after subarachnoid hemorrhage. J Neurosurg 2006; 105:723-9. 
5. Chia RY, Hughes RS, Morgan MK. Magnesium: a 11. useful adjunct in the prevention of cerebral vasospasm following aneurysmal subarachnoid haemorrhage. J Clin Neurosci 2002; 9:279-81.

6. Mori K, Miyazaki M, Iwata J, Yamamoto T, Nakao Y. Intracisternal infusion of magnesium sulfate solution improved reduced cerebral blood flow induced by experimental subarachnoid hemorrhage in the rat. Neurosurg Rev 2008; 31:197-203.

7. Chakraborti S, Chakraborti T, Mandal M, Mandal A, Das S, Ghosh S. Protective role of magnesium in cardiovascular diseases: a review. Mol Cell Biochem 2002; 238:163-79.

8. Han DH, Bai GY, Yang TK, Sim BS, Kwak YG, Kim CJ. The effect of papaverine on ion channels in rat basilar smooth muscle cells. Neurol Res 2007; 29:544-50.

9. Ko EA, Han J, Jung ID, Park WS. Physiological roles of $\mathrm{K}+$ channels in vascular smooth muscle cells. J Smooth Muscle Res 2008; 44:65-81.

10. Kim CJ, Han DH, Gwak YG. Effect of Tyrosine Kinase Inhibitors on the Calcium-Dependent K+ Current in Rat Basilar Smooth Muscle Cells. . J Korean Neurosurg Soc 2003; 33:393-8.
Standen NB, Quayle JM. K+ channel modulation in arterial smooth muscle. Acta Physiol Scand 1998; 164:549-57.

12. Zhang A, Cheng TP, Altura BM. Magnesium regulates intracellular free ionized calcium concentration and cell geometry in vascular smooth muscle cells. Biochim Biophys Acta 1992; 1134:25-29.

13. $\mathrm{Hu} \mathrm{L}$, Shi J, Ma Z et al. Participation of the S4 voltage sensor in the Mg2+-dependent activation of large conductance (BK) K+ channels. Proc Natl Acad Sci USA 2003; 100:10488-93.

14. Yang H, Hu L, Shi J, Delaloye K, Horrigan FT, Cui J. $\mathrm{Mg}^{2+}$ mediates interaction between the voltage sensor and cytosolic domain to activate BK channels. Proc Natl Acad Sci USA 2007; 104:182705 .

15. Zhang A, Cheng TP, Altura BT, Altura BM. Extracellular magnesium regulates intracellular free $\mathrm{Mg} 2+$ in vascular smooth muscle cells. Pflugers Arch 1992; 421:391-3. 